\title{
Sigara, Alkol veya Madde Kullanan Üniversite Öğrencilerinin Bağımlılığa Yönelik Farkındalık, Olumsuz Tutum ve Damgalama Düzeyleri
}

\author{
Levels of Awareness, Negative Attitudes and Stigma towards Addictions of \\ University Students Using Smoking, Alcohol, or Substances
}

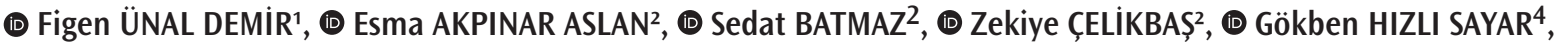 \\ (1) Hüseyin ÜNÜBOL ${ }^{3}$
}

${ }^{1} T$ Tokat Ruh Sağlığı ve Hastalıkları Hastanesi, Psikiyatri Kliniği, Tokat, Türkiye

${ }^{2}$ Tokat Gaziosmanpaşa Üniversitesi Tıp Fakültesi, Psikiyatri Anabilim Dalı, Tokat, Türkiye

${ }^{3}$ Üsküdar Üniversitesi Tıp Fakültesi, Psikiyatri Anabilim Dalı, İstanbul, Türkiye

\section{$\ddot{\mathrm{O} z}$}

Amaç: Bu çalışmada, üniversite öğrencilerinin tütün, alkol veya diğer madde kullanımlarına göre psikolojik sıkıntı düzeylerinin ve bağımlılık konusundaki farkındalık, olumsuz tutum ve damgalama düzeylerinin araştırılması amaçlanmıştır.

Yöntem: Çalıșmaya 612 üniversite öğrencisi dahil edilmiștir ve katılımcılar çevrimiçi olarak uygulanan Sosyodemografik Veri Formu, Bağımlılık Iç̧in Üç Boyutlu Farkındalık, Tutum ve Damgalama Ölçeği, Fagerström Nikotin Bağımlılık Testi, Alkol Kullanım Bozuklukları Tanıma Testi, Madde Kötüye Kullanımı Tarama Testi, Depresyon Anksiyete Stres 21 Ölçeğini yanıtlamıştır.

Bulgular: Çalışmamızda sigara içenlerde içmeyenlere göre anlamlı düzeyde daha yüksek stres, anksiyete, depresyon puanları; daha düşük farkındalık, daha düşük olumsuz tutum ve daha düşük damgalama puanları saptanmıştır. Alkol veya madde kullananlarda kulanmayanlara göre anlamlı düzeyde daha yüksek anksiyete puanları; daha düşük farkındalık, olumsuz tutum puanları saptanmıştır. Farkındalık ile olumsuz tutum, damgalama, sigara kullanım puanları arasında pozitif yönlü korelasyon saptanırken, farkındalık ile anksiyete ve alkol kullanım puanları ile negatif yönlü korelasyon saptanmıștır. Alkol kullanım puanları ile anksiyete, depresyon, stres, nikotin kullanım puanları arasında pozitif yönlü korelasyon tespit edilmiștir.

Sonuç: Alkol ve madde kullanımına sıklıkla psikiyatriksemptomlar eşliketmektedirve klinik değerlendirmede bu durum gözönünde bulundurulmalıdır. Özellikle riskli grup olan genç bireylerde bağımlılık konusunda farkındalığı artırmaya yönelik müdahaleler bağımlılığa karşı koruyucu olabilir.

Anahtar kelimeler: Bağımlıık, farkındalık, tutum, damgalama

\section{Abstract}

objective: The current study aimed to investigate the psychological distress levels of university students according to their tobacco, alcohol or other substance use and their awareness, negative attitude and stigmatization levels about addiction.

Method: 612 students were included in this study and they completed an online questionnaire consisting of the Sociodemographic Data Form, the Three-Dimensional Awareness for Addiction, Attitude and Stigma Scale, the Fagerström Test for Nicotine Dependence, the Alcohol Use Disorders Identification Test, the Drug Abuse Screening Test and the Depression Anxiety Stress 21 Scale.

Results: In our study, significantly higher stress, anxiety, depression scores, and lower awareness, negative attitude, stigmatization scores were determined in smokers than nonsmokers. Significantly higher anxiety scores, and lower awareness, negative attitude scores were found in alcohol or substance users than non-users. While there was a positive correlation between awareness and negative attitude, stigma, and smoking scores, there was a negative correlation between awareness and anxiety and alcohol use scores. A positive correlation was found between alcohol use scores and anxiety, depression, stress, and nicotine use scores.

Conclusion: Alcohol and substance use are often accompanied by psychiatric symptoms and this should be considered in clinical evaluation. Interventions for improving awareness about addiction, especially in young individuals who are at risk for addiction, may be protective against addiction.

Keywords: Addiction, awareness, attitude, stigma 


\section{Giriş}

Bağımlılık, anlamca geniş bir tanıma sahip olup genel olarak bir kișiye, nesneye, varlığa hissedilen engellenemez arzu duyma veya bir bașka iradenin yönetimi altına girme durumu olarak tanımlanabilir. Kișiler bu durumun ruhsal ve fiziksel sağlıklarını veya sosyal hayatlarını olumsuz etkilemesine rağmen bu durumu tekrarlamaya karșı önlenemez bir istek duyar ve sürdürürler (1).

Günümüzde madde bağımlılığı tanısı için somut kriterler, Ruhsal Bozuklukların Tanısal ve istatistiksel El Kitabında (DSM-5 veya Uluslararası Hastalıklar ve illgili Sağlık Sorunları Sınıflandırmasında (ICD-10) belirlenerek, bağımlıı̆̆ı teșhis etmek ve tedavisini değerlendirmek için yaygın olarak kullanılmaktadır (2).

Madde kullanımı ve madde kullanım bozukluğu sıklığı değerlendirildiğinde; Türkiye Bağımlılı̆̆ İzleme Merkezi'nin (TUBIM) 2019 yılına ait raporuna göre ortalama alkol, madde ve sigarayı ilk deneme yașı sırasıyla 19,4, 19,00 ve 17,85 olup, madde deneyenlerin \%65' i 15-34 yaș aralığındadır. Bu rapora göre madde kullananların \%86,8' i madde kullanmadan önce sigara, \%44,4' ü alkol kullandığını belirtmiștir (3). Üniversite yılları, kişinin hayatında entellektüel, sosyal ve duygusal bakımdan büyük değișimlerin olduğu yeni bir dönemdir (4). Üniversite öğrencileri bu yıllarda alkol, madde ve yasa dışı ilaç kullanımına eğilimli olmalarını sağlayan pek çok zorluk yaşarlar (5). Erken ve yetişkin stresli yaşam olaylarının, bağımlıı̆̆ın gelișimi için risk faktörleri olduğuna ve nüksleri tetiklediğine dair ikna edici kanıtlar vardır (6).

Depresyon ve anksiyete bozukluğu, madde kullanımı ve bağımlılığı ile birlikteliği en fazla olan ruhsal bozukluklardandır (7). Bu komorbidite için bir açıklama, duygu durum bozukluğu veya anksiyete bozukluğu olan bireylerin semptomlarla başa çıkmak için madde kullandığını öne süren self medikasyon hipotezidir ve zamanla, self medikasyon bağımsız bir madde kullanım bozukluğuna dönüșebilir (8). Majör depresif bozukluğu olan hastaların yaklaşık üçte birinde ayrıca madde kullanım bozuklukları vardır ve eş tanı, intihar riskinde artış ve işlevsellikte daha fazla bozulmaya neden olur (9). Schmidt ve arkadașlarının yaptığı prospektif çalışmada anksiyete duyarlıı̆̆ının alkol kullanım bozukluğu ile yüksek derecede ilişkili olduğu tespit edilmiştir (10). Depresyon ve anksiyete bağımlılığın oluşmasında rol oynayabileceği gibi bağımlılığın devam etmesinde de önemli bir faktör olarak karşımıza çıkar (11).

Madde bağımlılı̆ıında farkındalık, kișinin bağımlılık olușturan maddelerin, maddelerin etkisinin, bağımlılığın kişilerin hayatını nasıl etkilediğinin bilincinde olma durumları olarak tanımlanabilir (12).

Tutumlar; nesneler, insanlar ya da olaylarla ilgili değerlendirme ifadeleridir ve kişinin o şey ile ilgili ne hissettiğini belirtir (13).
Tutumların gerisinde tutumları oluşturan öge ise duygu ve düşünceler bağlamındaki farkındalıktır. Bağımlılık konusunda farkındalığı gelișmiş kişilerlerde olumlu tutum, farkındalığı gelișmemiş kişilerde ise olumsuz tutum olușması muhtemeldir. Olumlu tutum oluşan kișilerin bağımlı olma riski daha az, bağımlı olsalar bile tedaviye başlama ve sürdürme ihtimalleri daha fazlayken bu durum olumsuz tutum oluşan kişilerde tersidir (12). Farkındalıktaki artışın kişinin yaşadığı ruhsal sıkıntıyı, anksiyete ve depresyon belirtilerini azalttığını gösteren çalışmalar mevcuttur $(14,15)$. Ülkemizde yapılan toplumun ruhsal hastalıklara karşı tutumunu araştıran çalışmalarda ruhsal hastalığı olanlarla evlenmek, komșuluk etmek, evini kiraya vermek istememe oranlarının yüksek olduğu ve ruhsal hastalığı olanları tehlikeli görme gibi olumsuz tutumun yaygın olduğu söylenebilir $(16,17)$. Olumsuz tutum psikiyatrik hastalığı olan hastaların hastane başvurusunu geciktirmekte, azaltmakta ve ilaca uyumlarını bozmaktadır (18). Barry ve arkadașları yaptıkları bir çalıșmada toplumun \%90'ının ailesinden birinin madde kullanan biriyle evlenmesini, \%78' inin bu kișilerle yakın çalıșmayı istemediği, \%59' unun madde kullanım bozukluğunda tedavinin etkisiz olduğunu düşündüğünü, \%43’ ünün ev- sigorta yardımına karşı olduğunu saptamışlardır. Bu toplumda madde kullanım bozukluğu olanlara karșı da önemli ölçüde negatif tutum olarak değerlendirilmiștir (19).

Damgalama; bir kișinin veya belli bir topluluğun, toplumun genelinden ayrı tutulması, dıșlanması, değersizleștirilmesi, kusurlu olarak değerlendirilmesidir. İçelleștirilmiş damgalama ise kişilerin toplumun önyargılarını içselleștirmeleri ve bunun sonucunda kendilerine karșı olumsuz duygusal tepkiler oluşturmasıdır (20). Algılanan damgalanmanın daha düşük benlik saygısı, daha yüksek depresyon, kaygı ve daha kötü uyku ile ilişkili olduğunu, algılanan sosyal desteğin ise tam tersi etki yaptığını gösteren çalışmalar vardır (21). Hastaların içselleștirilmiş damgalanma düzeylerinin artmasıyla öz-yeterlik düzeylerinin düștüğü ancak tedavi motivasyon düzeylerinin arttığı görülmüștür (22).

Günümüzde pek çok ruhsal hastalık damgalanmaktadır. Ancak, madde kullanım bozukluğunun daha çok damgalandı̆̆ını ve toplumda sağlık sorunu olmaktan ziyade ahlaki bir bozukluk veya suç olarak algılandığını gösteren çalıșmalar vardır $(23,24)$. Özellikle yasa dışı maddeleri kullananların damgalanması kronik strese maruz kalma ve bakıma erişimde bir engel olarak bu kișilerin sağlığını da olumsuz etkileyebilmektedir (25). Alkol bağımlılarında suçluluk ve utanç duygularını araștıran bir çalıșmaya göre, hastalar remisyonda olsalar dahi bu duyguları, kontrol grubuna göre daha çok hissetmektedir (26). Suçluluk ve utanç hisseden kişiler bu duyguların azalması için başa çıkma yolu olarak tekrar alkol kullanmakta ve yineleyen alkol tüketiminin sonucu olarak yașanan bu olumsuz duygular da yinelemektedir. Bu kısır döngü hastaların tedavisini olumsuz etkilemekte ve hastalığın tekrarlamasını artırmaktadır (27). Çok 
sayıda çalışma damgalanmanın, sağlık hizmetleri ve madde kullanım tedavisi hizmetlerine ulaşımda büyük bir engel olduğunu göstermektedir (28).

Günümüzde alkol ve madde kullanım bozukluklarının artan yaygınlığı hem bireyler hem de toplumlar için ciddi sorunlar oluşturmaktadır. Genç nüfusun bağımlılık riski altında olması etkin önleme ve tedavi yöntemlerinin geliștirilmesini zorunlu kılmaktadır. Özellikle önleme müdahalelerinde gençlerde bağımlılıkla ilgili farkındalık, tutum, damgalamanın saptanması önem kazanmaktadır. Çalıșmamızda üniversite öğrencilerinin sigara, alkol ya da diğer madde kullanım durumlarına göre ruhsal sıkıntı düzeylerinin araştırılması ve bağımlılıkla ilgili farkındalık, olumsuz tutum ve damgalama düzeylerinin saptanması amaçlanmıştır.

\section{Yöntem}

\section{Örneklem}

Çalışmaya 628 üniversite öğrencisi katılmıştır. Bu öğrencilerden 16 'sının toplanan verilerinde \%10'dan fazla eksik mevcut olması nedeniyle bu öğrenciler çalıșmanın ilerleyen analizlerinden çıkarılmıştır. Dolayısıyla istatistikte 612 öğrenciden toplanan veriler kullanılmıştır. Çalışmaya dahil edilme ölçütleri: 1. Üniversite öğrencisi olmak, 2. 18 yaş veya daha büyük olmak, 3. İstenilen verilerde en fazla \%10 eksik olmak. Dışlama ölçütleri: 1. Üniversite öğrencisi olmamak, 2.18 yașından küçük olmak, 3. verilerinde \%10'dan fazla eksik olmak.

\section{İşlem}

Araştırma için Tokat Gaziosmanpaşa Üniversitesi Klinik Araştırmalar Etik Kurulu'ndan (11/06/2020 tarih ve 83116987278 sayılı) etik kurul onayı alınmıştır. Üniversite öğrencilerine kolayda örnekleme yolu ile farklı sosyal medya platformları ve e-posta grupları aracılığıyla ulaşılarak çalışmaya katılımları için davet metinleri yollanmıștır.

Çalışma için kullanılan elektronik formda ilk sayfada çalışma hakkında kısa bir bilgi yer almakta olup katılımcıların çalışmaya katılmaları konusunda gönüllü olup olmadıkları sorulmaktadır. Gönüllü olduğunu ve çalışma hakkındaki bilgileri okuyup anladığını beyan etmeleri halinde bir butonu ișaretlemeleri istenmektedir. Ancak bu butonun işaretlenmesi ile çalışmanın geri kalan bölümüne erişilebilmektedir. Bu ilk sayfanın ardından tüm katılımcılar için aynı sıralama içerisinde önce demografik verilerin sorgulandığı bir form çıkmaktadır. Burada katılımcılara sorular için işaretleyebilecekleri seçenekler sunulmaktadır. Sayfadaki sorular yanıtlandığında alt köșede yer alan bir buton aracılığıyla diğer sayfalara ilerlenmektedir. Bir ölçek doldurulduktan sonra geri dönerek işaretlemeleri değiştirmek mümkün değildir. Bu sayfalarda sırasıyla DASS-21, FNBT, AKBTT, DAST-10 ve Tutum Ölçeği yer almaktadır ve yukarıda şekilde seçenekler işaretlenerek doldurulmaktadır. Ölçeklerde soruların boş bırakılmasına izin verilmemektedir. Veri toplama setinde toplam sekiz sayfa ve 114 soru yer almaktadır. Ölçeklerin doldurulması için bir zaman sınırlaması yoktur, katılımcılar kendi hızlarında istedikleri gibi ölçekleri tamamlayabilmektedir. Ölçeklerin ne kadar sürede doldurulduğuna dair veriler kaydedilmemektedir. Bu nedenle bu çalışmada ölçeklerin ortalama doldurulma süresinin ne olduğuna dair veriler yoktur. En son ölçek tamamlandıktan sonra katılımcılara teșekkür edilmekte ve çekilişe katılmak istiyorlarsa e-posta adresi belirtmeleri istenmektedir. Aynı e-posta adresinin girilmesi halinde sistemde bu veriler işaretlenebilmektedir. Bu sayede aynı kișilerin birden fazla şekilde ölçek doldurmalarının önüne geçilmesi hedeflenmiştir. E-posta adresi girildiğinde sistem veri toplamayı sonlandırmakta ve otomatik olarak elektronik veritabanına kaydetmektedir. Ĕger katılımcılar ölçekleri tamamlamadan çalışmadan ayrılırlarsa veritabanından bu ölçeklerin ne kadarının doldurulduğuna dair istatistiklere ulaşılabilmektedir. Ölçekleri yarım bırakarak sonradan tamamlamaya devam etmek mümkün değildir, tüm ölçeklerin tek oturumda tamamlanması gerekmektedir.

\section{Veri Toplama Araçları}

\section{Demografik Veri Formu}

Araștırma örnekleminin tanımlanması ve araștırmanın değișkenleriyle ilgili olabilecek demografik bilgilerin saptanması amacıyla geliștirilen bu form, konuyla ilgili gerekli literatür taranmasından sonra araștırmacılarca hazırlanmıștır.

\section{Fagerström Nikotin Bağımlılık Testi (FNBT)}

Ölçek Heatherton ve ark. tarafından geliştirilmiştir (29). FNBT'nin Türkçe versiyonu Uysal ve arkadaşları tarafından yapılan güvenirlik ve faktör analizinde orta derecede güvenilir (Cronbach alfa: 0,56) bulunmuştur. Bu test sıklıkla nikotine fiziksel bağımlılı̆̆ ölçmek için kullanılan, her birine spesifik puanları olan 6 sorudan oluşan bir testtir. FNBT' de toplam skor eğer $\leq 4$ düşük bağımlılığı, 5 ise orta, eğer $\geq 6$ ağır sigara bağımlılığı olarak sınıflanır (30).

\section{Alkol Kullanım Bozuklukları Tanıma Testi (AKBTT)}

Ölçek Saunders ve ark. tarafından geliștirilmiştir (31). Türkçe versiyonunun geçerlik güvenirlik çalışması Saatçioğlu ve arkadașları tarafından yapılmıștır. Ölçeğin iç tutarlılığı iki farklı görüşmeci için 0,59 ve 0,65 olarak bulunmuştur. Ölçeğin testtekrar-test güvenirliği ise 0,90 'dır. Test, içme alışkanlıklarını, alkol tüketim miktarlarını ve alkol kullanımına ilişkin problemleri tespit eden 10 maddelik bir ölçektir. Ölçekten toplam 0 ile 40 arasında puan alınabilmektedir. Yapılan çalışmalarda farklı kesme noktaları olmakla birlikte önerilen kesme noktası 8'dir. Bu teste göre toplam puan $\leq 7$ ise tehlikesiz içme grubu, 8-14 aralığında ise tehlikeli içme grubu ve eğer $\geq 15$ ise potansiyel alkol bağımlısı grubundadır (32). 
Ölçek Skinner tarafından geliștirilmiştir (33). Çalışmamızda kullanılan Türkçe versiyonunun geçerlik güvenirlik çalıșması Evren ve arkadaşları tarafından yapılmıştır (Cronbach alfa: 0.92). Madde kullanımıyla ilișkili problemleri tanımlamak için oluşturulmuş olan bu test 10 sorudan olușmaktadır. Ters puanlanan 3. soru hariç diğerlerinde evet için 1 puan, hayır için 0 puan verilerek skorlanmaktadır. Testten alınan toplam puan 0 ile 10 arasında değişmektedir. Puan 0 ise problematik olmayan, 1-2 ise hafif problematik, 3-5 arası orta derecede problematik, ve $\geq 6$ ise ciddi problematik olarak sınıflanmaktadır (34).

\section{Bağımlılık İçin Üç Boyutlu Farkındalık, Tutum ve Damgalama Ölçeği}

Ölçek Potas ve arkadaşları tarafından geliştirilmiş̦tir. Illk 46 soru farkındalık, sonraki 7 soru tutum ve son 10 soru damgalamayı ölçmeye yöneliktir. Gençlerin madde bağımlıı̆ğı ve bağımlılarına ilişkin farkındalık düzeylerini belirlemeye yönelik olarak bilgi, kavrama, uygulama, analiz, sentez ve değerlendirme olmak üzere 6 boyuttan oluşan 5 li Likert tipinde düzenlenmiștir. Sonraki bölüm gençlerin madde bağımlılığı ve bağımlılarına ilișkin tutumlarını belirlemeye yönelik 7li Bogardus Tutum Ölç̣ği tipinde düzenlenmiş 7 maddeden olușmaktadır. Son bölümde ise madde bağımlılığı ve bağımlılarına ilişkin damgalama eğilimlerini belirlemeye yönelik 4'ü bağımlııı, 6'sı bă̆ımlılar olmak üzere 5li Likert tipinde düzenlenmiş 10 maddeden oluşmaktadır. Alınan yüksek puanlar madde bağımlıları ve bağımlılığına ilişkin daha yüksek farkındalık, olumsuz tutum ve daha yüksek damgalamayı yansıtmaktadır. Yapılan çalışmada conbach alfa değeri Farkındalık: 0.866, Olumsuz tutum 0,799, Damgalama: 0,807 olarak bulunmuştur (12).

\section{Depresyon Anksiyete Stres 21 Ölçeği (DASS 21)}

Lovibond ve Lovibond tarafından geliștirilen DepresyonAnksiyete-Stres Ölçeği 42 maddelik uzun formdan olușmaktadır (35). Henry ve Crowford DASÖ'nün 21 soruluk kısa formunu geliștirmiş ve güvenilirlik çalışmasıını yapmıştır (36). DASS 21 olarak isimlendirilen ve 21 maddeden oluşan DepresyonAnksiyete-Stres Ölçeği Kısa Formunun Türkçeye uyarlaması Yılmaz ve arkadașları tarafından yapılmıștır (Cronbach alfa: Depresyon: 0,819, Anksiyete: 0.808, Stres: 0,755). Depresyon, anksiyete ve stres için yedișer soru bulunmakta olup 4lü Likert tipinde düzenlenmiștir. Ölçek genelinde alınan puanların yüksek olması, bireyin depresyon, anksiyete ve stres alt boyutlarından hangilerinde problem yaşadığını ortaya koymaktadır (37).

\section{Veri Analizi}

Tüm istatistikler SPSS Statistics for Windows, Version 22.0 (IBM Corp, 2013) kullanılarak yapılmıștır. Katılımcıların demografik verileri tanımlayıcı istatistikler ile analiz edilmiş, ortalama (standart sapma) veya sıklık (yüzde) olarak bildirilmiștir. Gruplar arasında karșılaștırma yapmak için bağımsız örneklem t-testi ve ki-kare testi kullanıldı. İstatstiksel önemlilik için $p<0,05$ değeri anlamlı kabul edildi. Sigara, alkol ya da madde kullanım durumuna göre ruhsal sıkıntı düzeyi, bağımlıııla ilgili farkındalık, olumsuz tutum ve damgalama düzeylerinin çoklu grup karșılaștırmaları için uygulanan Bonferroni düzeltmesi sonrasında istatistiksel anlamlılık düzeyi $p<0,008$ olarak kabul edilmiștir. Bağımlılıkla ilgili farkındalık, olumsuz tutum ve damgalama düzeylerinin ruhsal sıkıntı düzeyleri, bağımlılık riskini değerlendirme ölçekleri ve birbirleriyle korelasyon ilișkisi iki değișkenli Pearson korelasyon incelemeleri ile değerlendirilmiş olup $p<0,05$ anlamlı, $p<0,01$ kuvvetli anlamlı olarak değerlendirilmiştir.

\section{Bulgular}

Öğrencilerin tanıtıcı özellikleri incelendiğinde ortalama yaş 25,58, katılımcıların \%86,1'i (n=527) kadın idi. Nikotin bağımlılığı oranları; hafif \%23,4, orta $\% 2,8$ ve ciddi nikotin bağımlılığı $\% 3,4$ olarak tespit edildi. Riskli alkol kullanım oranı \%2,5, risksiz alkol kullanım oranı \%23,4, alkol bağımlılığı oranı \%2 tespit edildi. DAST-10' a göre öğrencilerin \%10,3 ü düşük derece, \%1,3’ ü orta, $\% 0,3$ 'ü ciddi derecede madde kullanımı tarifledi.

Sigara kullananlarda kullanmayanlardan daha yüksek depresyon, anksiyete ve stres puanları bulunmuş olup aradaki fark istatistiksel olarak anlamlıdır (sırasıyla $\mathrm{t}(610)=-3,33$ $p=0,001, t(610)=-4,34 p<0,001, t(610)=-3,68 p<0,001)$. Sigara kullananlarda kullanmayanlardan daha düşük farkındalık, tutum ve damgalama puanları tespit edilmiștir (sırasıyla $\mathrm{t}(610)=5,12$ $p<0,001, t(610)=4,43 p<0,001, t(610)=3,07 p=0,002)$.

Alkol kullananlarda kullanmayanlardan daha yüksek anksiyete puanları saptanmıştır ( $t(610)=-3,11 p=0,002)$. Alkol kullananlarda kullanmayanlardan daha düşük farkındalık, tutum ve damgalama puanları tespit edilmiștir (sırasıyla $\mathrm{t}(610)=3,68$ $p<0,001, t(610)=3,86 p<0,001, t(610)=3,63 p<0,001)$

Madde kullananlarda kullanmayanlardan daha yüksek anksiyete puanları saptanmıștır $(\mathrm{t}(610)=-3,46 \mathrm{p}<0,001)$. Madde kullananlarda kullanmayanlardan daha düşük farkındalık ve tutum puanları tespit edilmiștir (sırasıyla; $\mathrm{t}(610)=9,19 \mathrm{p}<0,001$, $\mathrm{t}(610)=7,39 \mathrm{p}<0,001)$. (Tablo 1)

Bağımlılıkla ilgili farkındalık, olumsuz tutum ve damgalama düzeylerinin ruhsal sıkıntı düzeyleri, bağımlııı riskini değerlendirme ölçekleri ve birbiriyle korelasyonuna bakıldığında; farkındalık puanları ile tutum, damgalama ve nikotin bağımlıık test puanları arasında pozitif yönlü korelasyon saptanmıștır (sırasıyla $r=0,792 p<0,001, r=0,424 p<0,001, r=0,190 p<0,05$ ). Farkındalık ile anksiyete ve alkol kullanım test puanları arasında negatif yönlü korelasyon tespit edilmiștir (sırasıyla $r=-0,117$ $p<0,001, r=-0,132 p<0,05)$.

Alkol kullanım bozukluk tarama test puanları ile anksiyete, depresyon, stres ve nikotin bağımlıık test puanları arasında 
pozitif yönlü korelasyon saptanmıștır (sırasıyla $r=0,268 p<0,001$, $r=0,241 p<0,001, r=0,264 p<0,001, r=0,256 p<0,001)$.

Damgalama ve tutum puanları arasında da pozitif yönlü korelasyon saptanmıştır ( $r=0,532 \mathrm{p}<0,01)$. (Tablo 2)

\section{Tartışma}

Çalışmamızda üniversite öğrencilerinin sigara, alkol ya da diğer madde kullanım durumlarına göre ruhsal sıkıntı düzeyleri ve bağımlılıkla ilgili farkındalık, olumsuz tutum ve damgalama düzeyleri araştırılmış olup bunların birbirleriyle olan ilișkisi değerlendirilmiștir. Çalışmamızın önemli bulgularından birincisi; sigara içen ve içmeyen grupların stres, anksiyete ve depresyon test puanları arasında istatistiksel olarak anlamlı fark saptanmasıdır. Bu bulgu literatürdeki ruhsal sıkıntı ve sigara içme ilișkisini araștıran pek çok çalıșma ile uyumludur. Üniversite öğrencilerinde yapılan bir araștırmada halihazırda sigara içenlerin algılanan stres ortalama puanı, hiç sigara içmemiş ögrrencilerin puan ortalamasından önemli ölçüde daha yüksek bulunmuştur (38). 12-21 yaş arasındaki gençlerle yapılan bir başka araşırımada sigarayı denedikten sonra düzenli sigara kullanmaya başlayanların \%72' si bunun sebebinin stres olduğunu belirtmiștir. Aynı çalıșmada algılanan stres, mevcut sigara içen grupta en yüksek, deneme yapanlarda daha az ve hiç sigara içmeyenlerde en düşük olarak saptanmıștır (39). Lawles ve arkadaşları yaptıkları çalıșmada psikososyal stresin sigara içimi için önemli bir risk faktörü olduğunu, algılanan stres ile nikotin yoksunluk semptomatolojisinin arasında güçlü ilișki bulunduğunu ve stresin bu yoksunluk belirtilerini şiddetlendirebileceğini saptamışlardır (40). Literatürde anksiyete, depresyon ile sigara içme birlikteliğini gösteren pek çok çalıșma vardır (41). Depresyonu olan kișilerin, depresyonu olmayanlara kıyasla, sigara içme ve nikotin bağımlılığı kriterlerini karșılama olasılıkları daha yüksekken, sigarayı bırakma olasılıkları daha düșük ve nüksetme olasılıkları daha yüksektir (42). Sosyal anksiyete ve sigara içme isteği ilișkisini araștıran bir çalıșmada, yüksek sosyal anksiyetenin ve başa çıkma motivasyonlu içmenin sigara içmenin devamlılı̆ıında risk faktörü olduğunu, aşerme fazlalığının sigara içme sosyal anksiyete ilişkisiyle ilişkili olabileceği bulunmuştur (43). Mykletun ve ark. sigara kullanmış olup bırakanlar, hala içenler ve hiç sigara içmeyenlerde yaptıkları çalıșmada komorbid anksiyete-depresyon ile daha güçlü olmak üzere anksiyete ve depresyonla sigara içimini ilișkili bulmuşlardır. Anksiyete ve karıșık anksiyete-depresyon mevcut sigara kullananlarda sigarayı bırakmış olanlardan, sigarayı bırakmış olanlarda hiç içmemiş olanlardan daha fazla bulunmuştur (44).

Çalıșmamızın bir diğer bulgusu alkol ve madde kullanan gruplarda kullanmayanlardan istatistiksel olarak anlamlı yükseklikte anksiyete test puanları olmasıdır. Üniversite ögrencilerinde yapılan bir çalıșmada anksiyete duyarlılığı ve tehlikeli alkol içme arasındaki ilişki araştırı mış ve anksiyete

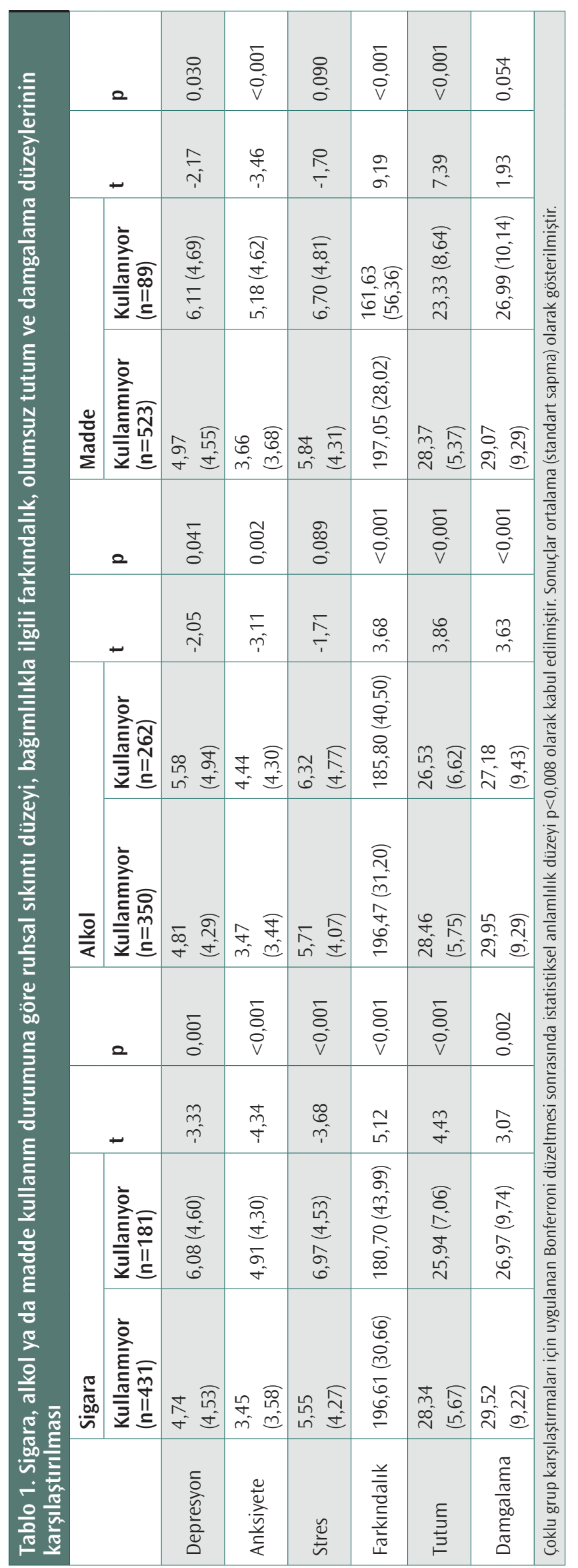


Tablo 2. Bağımlılıkla ilgili farkındalık, olumsuz tutum ve damgalama düzeylerinin ruhsal sıkıntı düzeyleri, bağımlılık riskini değerlendirme ölçekleri ve birbirleriyle korelasyon ilișkisi

\begin{tabular}{|c|c|c|c|c|c|c|c|c|c|}
\hline & Farkındalık & Tutum & Damgalama & Depresyon & Anksiyete & Stres & FNBT & АKBTT & МККТТ \\
\hline Farkındalık & 1 & & & & & & & & \\
\hline Tutum & $0,792^{* *}$ & 1 & & & & & & & \\
\hline Depresyon & $-0,064$ & $-0,001$ & 0,066 & 1 & & & & & \\
\hline Anksiyete & $-0,117^{* *}$ & $-0,064$ & 0,017 & $0,682^{* *}$ & 1 & & & & \\
\hline FNBT & $0,190^{*}$ & 0,141 & $-0,127$ & 0,055 & 0,102 & 0,035 & 1 & & \\
\hline AKBTT & $-0,132^{*}$ & $-0,084$ & $-0,018$ & $0,241 * *$ & $0,268 * *$ & $0,264 * *$ & $0,256^{* *}$ & 1 & \\
\hline MKKTT & $-0,098$ & $-0,047$ & $-0,149$ & 0,008 & 0,043 & 0,042 & 0,050 & 0,109 & 1 \\
\hline
\end{tabular}

duyarlılığı yüksek olanlarda tehlikeli içiciliğin de fazla olduğu saptanmıștır. Anksiyete duyarlılığı yüksek olan tehlikeli alkol kullanımı olanlar, normal anksiyete duyarlııı̆ına sahip olanlardan daha şiddetli içme ve daha fazla diğer madde kullanımı göstermiștir (45). Yapılan bir epidemiyolojik çalıșmada șiddetli depresyon ve/veya anksiyete semptomları olan bireylerde alkol ve madde kullanımı riskinin daha az şiddetli semptomatolojiye sahip bireylerde görülenden daha yüksek olduğunu vurgulanmaktadır. Yine bu çalıșmada depresyonun madde kullanımı için çok yüksek risk oluşturduğu saptanmıştır (46).

Alkol ve madde kullanan pek çok kişi bunların antidepresan ve anksiyolitik etkisi olduğunu belirtir, ancak aradaki ilișki net değildir. Aradaki ilişki self medikasyon amaçlı alkol-madde kullanımına bağlı olabileceği gibi bunların nörotransmitterler üzerinden yaptığı negatif afekt etkisiyle psikiyatrik semptom artışı da olabilir. Ya da sebep sonuçtan ziyade aynı risk faktörleri nedeniyle bu birliktelik sık görülüyor olabilir $(47,48)$. Bizim çalışmamızda alkol veya madde kullananlarla kullanmayanların anksiyete puanları arasında istatistiksel anlamlı fark varken depresyon puanları arasında fark bulunmamıștır. Bu literatürde genel olarak alkol madde kullanımının depresyonla da ilișkili olduğunu gösteren çalışmalarla uyumsuzdur (9). Çalıșmamızda alkol ve madde kullananların büyük kısmının düşük dereceli kullanıcı olması bu sonuçta etkili olabilir. Yapılan korelasyon analizinde alkol kullanım puanları ile depresyon, anksiyete, stres ve nikotin kullanma puanları arasında pozitif yönlü korelasyon bulunmaktadır. Psikiyatrik belirtiler ile alkol kullanımı arasında ilișki çalıșmamızda daha önce belirtilmiștir. Literatür bilgisi ve çalıșmamızın sonuçlarından yola çıkarak psikiyatrik semptomların alkol, madde ve sigara kullanmaya bașlamada, sürdürmede ve bırakmayı zorlaștırmada önemli bir etken olduğu söylenebilir. Psikiyatrik semptom birlikteliği tedavi şeklini, alkol ve madde madde tedavisinin prognozunu değiştirebilmektedir. Stres açııından risk altında olan üniversite öğrencilerinde psikiyatrik belirtilerin tanınması ve yönetilmesi, buna yönelik eğitimlerin planlanması alkol ve madde ile ilgili sorunların çözümüne katkı sağlayacaktır.

Önemli sonuçlarımızdan bir diğeri alkol, madde veya sigara kullanmayanlarda kullananlara göre istatistiksel olarak anlamlı ölçüde daha yüksek farkındalık ve olumsuz tutum test puanları saptanmış olmasıdır. Bununla birlikte alkol ve sigara kullanmayanlarda kullananlara göre istatistiksel olarak anlamlı derecede daha yüksek damgalama test puanları saptanmıştır. Literatürde farkındalık ile alkol kullanımı arasında pozitif yönlü ilişki olduğunu gösteren çalışmalar (49) olsa da negatif yönlü ilişki olduğunu gösteren çok sayıda çalıșma mevcuttur (50-52). Levin ve arkadașlarının ayaktan tedavi bașvurusunda bulunan psikiyatri hastalarında yaptığı çalıșmada alkol ve madde kullanmayan grubun farkındalık puanları alkol veya madde kullanmakta olan gruba göre daha yüksek bulunmuștur, ancak sigara içen ve içmeyenler arasında fark bulunmamıștır (53). Bowenin yaptığı bir çalıșmada madde kullanımı nedeniyle tedavi arayan yetișkinlerde farkındalık ve bağımlılı̆ın şiddeti arasında negatif bir ilişki ortaya konmuştur (54).

Çalışmamızda farkındalıkla anksiyete düzeyleri arasında negatif yönlü korelasyon saptanmış̦ır. Farkındalığın olumsuz duyguların düzenlenmesinde etkili olması anksiyetenin azalmasında etkilidir (15). Gebelerde yapılan bir çalıșmada farkındalıktaki artışın anksiyetede azalma ile ilișkili olduğu bulunmuştur (14). Çalıșmamızın bu bulgusu literatürdeki çalıșmalarla uyumludur (55,56). Alkol, madde kullananlar ve kullanmayanların farkındalık puanları karșılaştıııldığında literatürle tutarlı bulgular elde edilmiștir. Ancak korelasyon analizleri sonucunda farkındalıkla alkol kullanımı arasında negatif yönlü korelasyon bulunmuş olması literatürle uyumlu iken farkındalık test puanlarıyla nikotin kullanımı test puanları arasında pozitif yönlü ilișki bulunmuş olması ve madde kullanım puanları arasında istatistiksel olarak anlamlı ilişki bulunmamış olması literatürle 
genel olarak uyumlu olmayan bulgulardır. Bunun sebebi seçilen örneklemin kullanılan madde açısından homojen olmaması veya kullanılan ölçüm araçlarının farkıılığı olabilir.

Çalışmamızda kullanılan Bağımlılık Iç̧in Üç Boyutlu Farkındalık, Tutum ve Damgalama Ölçeği farkındalık, tutum ve damgalama olmak üzere üç boyuttan oluşmakta olup bu üç boyut birbiriyle ilișkilidir. Kișinin farkındalık düzeyinden bağımsız olarak farkındalığın kişinin tutumunu doğrudan etkilediği, tutumun ise damgalama düzeyini etkilediği düşünülmektedir (12). Bizim çalıșmamızda da farkındalık ile tutum ve damgalama puanları, tutum ile damgalama puanları arasında pozitif yönlü korelasyon saptanmıștır. Alkol ve madde kullananlara karșı toplumun tutumunu araștıran çalıșmalarda genel olarak olumsuz tutum ve damgalama olduğu tespit edilmiștir $(19,25)$. Türkiye' de toplumun bağımlılık yapıcı madde kullananlara karșı tutum ve davranıșlarını araștıran bir çalıșmada sigara, alkol ve bağımlıık yapıcı maddeleri hiç kullanmamış olan bireylerin, madde kullanan bireylere karșı olumsuz tutumlarının diğer katılımcılardan daha fazla olduğu saptanmıștır (57). Sağlık çalışanlarında yapılan çalıșmalarda da benzer sonuçlar elde edilmiștir. Bununla birlikte sağlık hizmeti sunucuları bağımlılık hizmetlerinde çalışan profesyoneller olduğunda, bu hasta popülasyonuna bakma konusunda daha fazla deneyime sahip olduklarında veya madde kullanan hastalarla daha fazla kişisel temasa sahip olduklarında olumlu tutumlar rapor edilmiștir (58). Damgalama toplumun bireyi damgalaması olabileceği bireyin de kendini damgalaması olarak da karşımıza çıkmaktadır. Bunların sonucunda alkol, madde kötüye kullanımı olan birey daha da yalnızlașmakta, depresyon sıklığı artmakta, uyku bozukluğu, kendine güvensizlik, suçluluk ve utanç duyguları gelişebilmekte ve kișiler bazen tedavi arayıșından vazgeçebilmektedir. Hastalar bu duygularla başa çıkabilmek için tekrar alkol madde kullanmaya așlayarak kısır döngüye girebilmektedir $(21,27)$.

Alkol madde bağımlılığının tedavisinde önemli engellerden olan olumsuz tutum ve damgalanmanın önlenmesi bağımlı kişilerin sosyal hayatın ve tedavinin içinde kalabilmesi için önemlidir. Bunun sağlanabilmesi için toplumsal eğitimler verilebilir. Bağımlı kişiye uygulanacak kendini damgalamayı önlemeye yönelik müdahaleler, kişinin kısır döngüden çıkmasını sağlayabilir ve tedaviye katııımını artırılabilir. Damgalamanın azalmasıyla bağımlı kișilerin hayatındaki maddi zorlanmaların da azalabileceği bunun da stres, anksiyete ve depresyon oranlarında azalma sağlayarak alkol madde kullanımında azalma sağlayabileceği söylenebilir.

Çalıșmamızın bazı kısıtlılıkları bulunmaktadır. Kesitsel bir çalışma olması, verilerin çevrimiçi bir anketle özbildirim ölçekleri kullanılarak toplanmış olması ve tanısal klinik görüșme yapılmamış olması bu kısıtılıklar arasındadır. Bununla birlikte çalışmamızın bazı güçlü yanları da bulunmaktadır. Literatürde, farkındalık ile alkol, madde ve sigara kullanımı arasındaki ilișkiyi araştıran yayınların çoğu farkındalık temelli terapilerin etkinlikleri üzerinden yapılmış olup sigara, alkol ya da diğer madde kullanım durumlarına göre ruhsal sıkıntı düzeyleri ve bağımlılıkla ilgili farkındalık, olumsuz tutum ve damgalama düzeyleri ilișkisini araștıran çalışma sayısı çok kısıtlıdır.

Sonuç olarak madde bağımlılı̆̆ ve psikiyatrik semptomlar arasında karșılıklı bir ilișki olup farkındalığın artması hem psikiyatrik semptomlara hem de madde kullanımına karșı koruyucu olabilmektedir. Öte yandan madde kullanan bireylere karșı toplumun olumsuz tutumu ve damgalaması madde kullanan bireylerin tedavisini zorlaştırmaktadır. Özellikle risk altındaki genç bireylere verilecek eğitimler bu problemlerin tanınmasına ve çözümüne katkı sağlayabilir. Aradaki ilișkilerin daha iyi anlaşılabilmesi için daha büyük örneklemlerde yapılacak çalıșmalara intiyaç vardır.

\section{Kaynaklar}

1. Uzbay IT. Madde bağımlılığının tarihçesi, tanımı, genel bilgiler ve bağımlılık yapan maddeler. Türk Eczacıları Birliği Meslek İçi Sürekli Eğitim Dergisi 2009; (21): 5-15.

2. Camí J, Farré M. Drug addiction. N Engl J Med 2003; 349(10): 975-986.

3. T.C. İçișleri Bakanlığı Emniyet Genel Müdürlüğü Narkotik Suçlarla Mücadele Daire Bașkanlığı, Türkiye Uyușturucu Raporu 2019. Ankara, TUBiM, 2019: 91-96.

4. Sönmez E, Akvardar Y. Gençlerde madde kullanımının önlenmesinde sosyal norm yaklașımı "Daha çok içtiğini düşünürsem, daha çok içerim”. Bağımlılık Dergisi 2015; 16(2): 86-94.

5. Skidmore CR, Kaufman EA, Crowell SE. Substance use among college students. Child Adolesc Psychiatr Clin N Am 2016; 25(4): 735-753.

6. Cadet JL. Epigenetics of stress, addiction, and resilience: therapeutic implications. Mol Neurobiol 2016; 53(1): 545-560.

7. Gil-Rivas V, Prause JA, Grella CE. Substance use after residential treatment among individuals with co-occurring disorders: the role of anxiety/ depressive symptoms and trauma exposure. Psychol Addict Behav 2009; 23(2): 303-314.

8. Turner S, Mota N, Bolton J, Sareen J. Self-medication with alcohol or drugs for mood and anxiety disorders: A narrative review of the epidemiological literature. Depress. Anxiety 2018; 35(9): 851-860.

9. Davis L, Uezato A, Newell JM, Frazier E. Major depression and comorbid substance use disorders. Curr Opin Psychiatry 2008; 21(1): 14-18.

10. Schmidt NB, Buckner JD, Keough ME. Anxiety sensitivity as a prospective predictor of alcohol use disorders. Behav Modif 2007; 31(2): 202-219.

11. Sinha R. The role of stress in addiction relapse. Curr Psychiatry Rep 2007; 9(5): 388-395.

12. Potas N, Erçetin SS, Yilmaz M, et al. 3D scale for awareness, attitude, stigma of addiction. Stud Ethno-Medicine 2016; 10(2): 156-165.

13. Robbins S. Örgütsel Davranıșın Temelleri, Sevgi Ayşe Öztürk (çeviren). Eskişehir: ETAM Basım Yayın, 1994.

14. Yüksel A, Dabanlı Z, Bahadır Yılmaz E. Gebelerde bilinçli farkındalık ile depresyon, anksiyete ve stres düzeyleri arasındaki ilişkinin belirlenmesi. Jaren 2020; 6(2): 195-202.

15. Önder Cenkseven F, Utkan Ç. Bilinçli farkındalık ve algılanan stres ilişkisinde ruminasyon ve olumsuz duygu düzenlemenin aracı rolü. Mersin Üniversitesi 
Eğitim Fakültesi Dergisi 2018; 14(3): 1004-1019.

16. Taşkın EO, Şen FS, Aydemir Ö, et al. Türkiye'de kırsal bir bölgede yaşayan halkın şizofreniye ilişkin tutumları. Türk Psikiyatri Derg 2002; 13: 205-214.

17. Taşkın EO, Özmen E, Yüksel EG, Deveci A. Depresyonlu hastaların depresyona yönelik tutumları. Türkiye'de Psikiyatri 2005; 7: 44-53.

18. Çam 0, Bilge A. Türkiye' de ruhsal hastalığa/ hastaya yönelik inanç, tutum ve damgalama süreci: sistematik derleme. Psikiyatri Hemșireliği Dergisi Journal of Psychiatric Nursing 2013;4(2): 91-101

19. Barry CL, McGinty EE, Pescosolido BA, Goldman HH. Stigma, discrimination, treatment effectiveness, and policy: Public views about drug addiction and mental illness. Psychiatr Serv 2014; 65(10): 1269-1272.

20. Corrigan PW, Larson JE, Kuwabara SA. Social psychology of the stigma of mental illness: public and self-stigma models. Maddux JE, Tangney JP (editors). Social Psychological Foundations of Clinical Psychology. 1. Baskı, New York: The Guilford Press, 2010: 51-71.

21. Birtel MD, Wood L, Kempa NJ. Stigma and social support in substance abuse: Implications for mental health and well-being. Psychiatry Res 2017; 252: $1-8$.

22. Bozdağ N, Çuhadar D. Internalized stigma, self-efficacy and treatment motivation in patients with substance use disorders. J Subst Use 2021; doi: 10.1080/14659891.2021.1916846).

23. Rao H, Mahadevappa H, Pillay $\mathrm{P}$, et al. A study of stigmatized attitudes towards people with mental health problems among health professionals. J Psychiatr Ment Health Nurs 2009; 16(3): 279-284.

24. Radcliffe P, Stevens A. Are drug treatment services only for "thieving junkie scumbags"? Drug users and the management of stigmatised identities. Soc Sci Med 2008; 67(7): 1065-1073.

25. Ahern J, Stuber J, Galea S. Stigma, discrimination and the health of illicit drug users. Drug Alcohol Depend 2007; 88(2-3): 188-196.

26. Kalyoncu ÖA, Mırsal H, Pektaş Ö, et al. Alkol bağımlılarında suçluluk ve utanç duyguları. Bağımlılık Dergisi 2002; 3(3): 160-164.

27. Çam 0, Ayakdaş Dağlı D. Alkol bağımlılarında içselleştirilmiş damgalama, suçluluk ve utanç duyguları. Bağımlılık Dergisi 2017; 18(4): 145-151.

28. Clement S, Schauman O, Graham T, et al. What is the impact of mental health-related stigma on help-seeking? A systematic review of quantitative and qualitative studies. Psychol Med 2015; 45(1): 11-27.

29. Heatherton TF, Kozlowski LT, Frecker RC, Fagerström KO. The Fagerström Test for Nicotine Dependence: a revision of the Fagerström Tolerance Questionnaire. Br J Addict 1991; 86(9): 1119-1127.

30. Uysal MA, Kadakal F, Karşıdağ Ç, et al. Fagerstrom test for nicotine dependence: reliability in a Turkish sample and factor analysis. Tüberk Toraks Derg 2004; 52(2): 115-121.

31. Saunders JB, Aasland OG, Babor TF, et al Development of the alcohol use disorders Identification test (AUDIT): WHO collaborative project on early detection of persons with harmful alcohol consumption--II. Addiction 1993; 88(6): 791-804.

32. Saatçioğlu Ö, Evren C, Çakmak D. Alkol kullanım bozuklukları tanıma testinin geçerliği ve güvenirliği. Türkiye'de Psikiyatri 2002; 4(2-3): 107-113.

33. Skinner HA. The drug abuse screening test. Addict Behav 1982; 7(4): 363-371.

34. Evren C, Can Y, Yılmaz A, et al. Psychometric properties of the drug abuse screening test (DAST-10) in heroin dependent adults and adolescents with drug use disorder. Dusunen Adam 2013; 26: 351-359.
35. Lovibond PF, Lovibond SH. The structure of negative emotional states: comparison of the Depression Anxiety Stress Scales (DASS) with the Beck Depression and Anxiety Inventories. Behav Res Ther 1995; 33(3): 335-343.

36. Henry JD, Crawford JR. The short-form version of the depression anxiety stress scales (DASS-21): construct validity and normative data in a large nonclinical sample. Br J Clin Psychol 2005; 44(2): 227-239.

37. Yılmaz Ö, Boz H, Arslan A. Depresyon anksiyete stres ölçeğinin (DASS 21) Türkçe kısa formunun geçerlilik-güvenilirlik çalışması. Finans Ekonomi ve Sosyal Araştırmalar Dergisi 2017; 2(2): 78-91.

38. Naquin MR, Gilbert GG. College students' smoking behavior, perceived stress, and coping styles. J Drug Educ 1996; 26(4): 367-376.

39. Siqueira L, Diab M, Bodian C, Rolnitzky L. Adolescents becoming smokers: The roles of stress and coping methods. J Adolesc Health 2000; 27(6): 399408.

40. Lawless MH, Harrison KA, Grandits GA, et al. Perceived stress and smokingrelated behaviors and symptomatology in male and female smokers. Addict Behav 2015; 51: 80-83.

41. Fluharty M, Taylor AE, Grabski M, Munafò MR. The association of cigarette smoking with depression and anxiety: A systematic review. Nicotine Tob Res 2017; 19(1): 3-13.

42. Weinberger AH, Desai RA, McKee SA. Nicotine withdrawal in U.S. smokers with current mood, anxiety, alcohol use, and substance use disorders. Drug Alcohol Depend 2010; 108(1-2): 7-12.

43. Watson NL, DeMarree KG, Cohen LM. Cigarette craving and stressful social interactions: The roles of state and trait social anxiety and smoking to cope. Drug Alcohol Depend 2018; 185: 75-81.

44. Mykletun A, Overland S, Aaro LE, et al. Smoking in relation to anxiety and depression: Evidence from a large population survey: The HUNT study. Eur Psychiatry 2008; 23: 77-84.

45. Paulus DJ, Zvolensky MJ. The prevalence and impact of elevated anxiety sensitivity among hazardous drinking college students. Drug Alcohol Depend 2020; 209: 107922.

46. Rudenstine S, Espinosa A, Kumar A. Depression and Anxiety Subgroups Across Alcohol Use Disorder and Substance Use in a National Epidemiologic Study. J Dual Diagn 2020; 16(3): 299-311.

47. Dilbaz N, Yılmaz O. Duygudurum bozuklukları ve alkol ve madde kullanım bozukluğu eș tanısı ve tedavisi. Karamustafalıoğlu KO (editör). Bipolar Bozukluk. 1. Baskı. Ankara: Türkiye Klinikleri; 2019: 27-34.

48. Vorspan F, Mehtelli W, Dupuy G, et al. Anxiety and substance use disorders: co-occurrence and clinical Issues. Curr Psychiatry Rep 2015; 17(2): 4.

49. Leigh J, Neighbors C. Enhancement motives mediate the positive association between mind/body awareness and college student drinking. J Soc Clin Psychol 2009; 28(5): 650-669.

50. Bodenlos JS, Noonan M, Wells SY. Mindfulness and alcohol problems in college students: The mediating effects of stress. J Am Coll Heal 2013; 61(6): 371-378.

51. Fernandez AC, Wood MD, Stein LAR, Rossi JS. Measuring mindfulness and examining its relationship with alcohol use and negative consequences. Psychol Addict Behav 2010; 24(4): 608-616.

52. Bramm SM, Cohn AM, Hagman BT. Can preoccupation with alcohol override the protective properties of mindful awareness on problematic drinking? Addict Disord Their Treat 2013; 12(1): 19-27.

53. Levin ME, Dalrymple K, Zimmerman M. Which facets of mindfulness predict the presence of substance use disorders in an outpatient psychiatri sample? Psychol Addict Behav 2014; 28(2): 498-506. 
54. Bowen S, Enkema MC. Relationship between dispositional mindfulness and substance use: Findings from a clinical sample. Addict Behav 2014; 39(3): 532-537.

55. Özyeșil Z, Arslan C, Kesici ş, Deniz ME. Bilinçli Farkındalık Ölçeği’ni Türkçeye Uyarlama Çalıșması. Eğitim ve Bilim 2011; 36(160): 226-227.

56. Roemer L, Lee JK, Salters-Pedneault K, et al. Mindfulness and emotion regulation difficulties in generalized anxiety disorder: preliminary evidence for Independent and overlapping contributions. Behav Ther 2009; 40(2): 142-154.
57. Yılmaz G, Kaylı DŞ. Toplumun bağımlılık yapıcı madde kullanan bireylere yönelik tutum ve davranışları: Manisa ili örneği. Celal Bayar Üniversitesi Sosyal Bilimler Dergisi 2020; 18(1): 326-338.

58. Van Boekel LC, Brouwers EPM, Van Weeghel J, Garretsen HFL. Stigma among health professionals towards patients with substance use disorders and its consequences for healthcare delivery: Systematic review. Drug Alcohol Depend 2013; 131(1-2): 23-35. 